\title{
Article
}

\section{Tree Resin as the Most Macroergic Constituent of Conifers - a possible means to mitigate global warming and climate change}

\author{
Jaroslav Demko ${ }^{1}$, Ján Machava ${ }^{1}$ \\ Catholic university in Ruzomberok, Faculty of Education, Department of Biology and Ecology, Hrabovska cesta 1, 03401 Ruzomberok, Slovakia \\ * Correspondence: SK, jnmchv9@gmail.com; Tel.: +421-905-756824
}

\begin{abstract}
Tree resin, which in addition to its widespread use in industry is also a macroergic component which has not yet been used for energy purposes. The main goal of this work is to determine the energy content of the resin of spruce, pine and larch and wood components - pulp and turpentine. The combustion heats of resin $(\mathrm{MJ} / \mathrm{kg})$ from each timber was determined calorimetrically. The energy values of tree resin $\left(>38.0 \mathrm{MJ} . \mathrm{kg}^{-1}\right)$ were 2.2 and 2.4 times higher than that of bleached and unbleached cellulose, the highest value was recorded for the turpentine $\left(>39.0 \mathrm{MJ} . \mathrm{kg}^{-1}\right)$. The best way of resin tapping is the America method, providing $5 \mathrm{~kg}$ resin $\mathrm{ha}^{-1} \mathrm{yr}^{-1}$. The resin quantity tapped was raised at least 3 times applying stimulant, its production cost compared to other feedstocks was the cheapest. The tree resin can be applied as a good means to mitigate global warming and consequently dampen climate change. One tonne of tree resin burned instead of coal spares the atmosphere by $5.0 \mathrm{Mt} \mathrm{CO}_{2}$ since it is environmentally neutral. As resin heating values approach to the lower end of ones of liquid hydrocarbon fuels, greater efforts are needed to examine the most efficient energy use of resin.
\end{abstract}

Keywords: resin; soft- and hardwood; combustion heat; pulp; renewable source; carbon sequestration, climate change

\section{Introduction}

According to the European Union policy (Directive 2009/28/EC) 20\% of overall energy consumption in the EU by 2020 energy should be superseded by renewable sources. In this respect, adequate findings must be obtained for characterization and identification of biomass specific types because forest biomass quality is closely associated with its composition [1] and stand characteristics [2]. What is more, biomass resources used for energy purposes simultaneously serve for carbon sequestration lowering its content in the atmosphere [3]. A more detailed study of the energy issue of resin as an important component of tree biomass is therefore very necessary.

Resins are related to a family of extractive substances such as waxes, suberin, cutin, glycosides, alkaloids and others that protect the plants against unfavourable biotic and abiotic influences [4 - 9]. Resin can be chemically characterized as a group of aromatic compounds of a terpene nature and is formed by two major classes of substances - the first group of compounds derived from phenylpropane and the second one from terpene compounds. Resin is a mixture of various substances, of which resin acids, terpene-type hydrocarbon, terpenoid alcohols, waxes, the solution of relatively light or volatile terpenes are the most important [10 -13]. The terpenes are largely monoterpenes that generally comprise about 25 percent of the total weight of resin. The remainder of the liquid fraction is chiefly sesquiterpenes $(0-20 \%)$. Thus, the aggregate of all terpenes in whole resin is in the range 25-45 percent [14]. It is generally agreed that terpenes are formed by polymerization of isoprene $\left(\mathrm{C}_{5} \mathrm{H}_{8}\right)$ from hemiterpenes through the monoterpenes up to polyterpenes (including rubber and gutta) $[15,16]$.

Tree resin is a complex mixture of volatile and non-volatile terpenes. Mono- $\left(\mathrm{C}_{10} \mathrm{H}_{16}\right)$, and sesquiterpenes $\left(\mathrm{C}_{15} \mathrm{H}_{24}\right.$, turpentine; farnesyl diphosphate, FPP) generally are volatile, giving fluidity to the resin and usually give resin its characteristic odour. (When only the volatile mono- and sesquiterpenes occur, they often are called essential oils. This designation, however, is misleading because these terpenoids are neither essential to plant metabolism nor are they true oils; essential refers to their essence or fragrance, and oil to their feel). Turpentine constitutes the largest group of secondary products and derive from a 5C compound, IPP (isopentenyl pyrophosphate). Non-volatile diterpenic $\left(\mathrm{C}_{20} \mathrm{H}_{32}\right.$, rosin); the most frequent and abundant diterpenoid resin compounds occurring in rosin are derivatives of abietane, pimarane, and isopimarane skeletons $[17,18]$. Diterpene acids are particularly important in resin. Doubling (dimerization) of the $\mathrm{C}_{15} \mathrm{H}_{24}$ (FPP) leads to $\mathrm{C}_{30} \mathrm{H}_{52}$ compounds, the triterpenes. Triterpenes include a wide variety of structurally diverse substances. This terpene fractions make up a valuable natural source of materials for chemical industries [19].

In the wording of the previous text, the plant resin can be defined as primarily a lipid-soluble mixture of volatile and non-volatile terpenoid and/or phenolic secondary compounds that are usually secreted in specialized structures 
located either internally or on the surface of the plant and of potential significance in ecological interactions [10]. Resin is sometimes confused with oleoresin. Oleoresins are comparatively fluid terpenoid resins with a higher ratio of volatile to non-volatile terpenes. Hereinafter, the resin will be mostly referred to as oleoresin.

After the collection, the crude resin conversion into gum turpentine and gum rosin is carried out by steam distillation [20]. Subsequently, these by-products are processed for use in fabrication of diverse industrial products such as feedstock, cleaners, pine oil, fragrances and flavouring compounds, pesticides, solvent and thinner for paints and pharmaceuticals products [21-23]. Most Pinus species yield pinenes ( $\alpha$ - and/or $\exists$-pinene) as major compounds in their monoterpenic turpentine fraction. Large amounts of pinenes are used in the flavour and fragrance industry [24]. Albeit due to their strong odour they can't be extensively used as additives in flavour and fragrance, pinenes are chemically converted to more valuable products such as verbenone, a monoterpene which exhibits ecological role as antiaggregating pheromone (tree protection) ([25-30]. Besides this, pinenes might also be used in the production of pharmaceuticals, plasticizers, repellents, insecticides, solvents, perfumery, cosmetics, antiviral and antimicrobial compounds [26-32]. Some investigations have been carried out with the aim of assessing the economic viability of performing resin-tapping operations [21, 33, 34, 35].

The combustion heat and the calorific value of the stump wood, tree crown components and assimilatory organs are relatively well known [36 - 38] and fluctuate depending on tree species. For chestnut and pine, the crown fraction generates the highest and the wood the lowest energetic values. The calorific value per a tree was lowest for chestnut (17.419 MJ.kg-1), intermediate for Short-Rotation Coppice crops (18.185 - $\left.18.419 \mathrm{MJ} . \mathrm{kg}^{-1}\right)$, and highest for maritime pine (19.336 MJ.kg-1) [38].This is caused by the higher lignin and resin contents in coniferous species. These results are consistent with the trends observed by Telmo [39] who reported higher energetic values for different pine species that for native broad leaved and autochthonous species in northern Portugal. Wood extractives such as resin, waxes, oils, tannins, and other phenolic substances also have much higher heating values than cellulose and hemicelluloses and they are abundant in the wood of coniferous species [40]. The content of terpenes and oleoresins significantly affect the energetic values of "lignocellulosic fuels". Furthermore, Howard [41] has calculated the higher heating values of resin as 15,000 to $16,000 \mathrm{Btu} / \mathrm{lb}\left(34.890-37.216 \mathrm{MJ} . \mathrm{kg}^{-1}\right)$, however the variation of results was large, as resin samples were semiliquid and rather inhomogeneous. In follow-up on the knowledge stated, this work examines the properties of tree resin and its potential for a renewable energy source.

\subsection{Problems}

The resins are macroergic solids (high energy), which are formed similarly to the essential oil in specific resin canals. The physiological resin is formed by the metabolic activity of trees, pathological resin is mainly produced as a result of an injury to the trees. The amount and composition of the resin in various types of wood depends largely on the biochemical taxon of individual species, environmental effects [42], geographic origin [43], and local conditions [44, 45] etc.

Significant differences in the composition of resin were found not only between different coniferous trees, but also between trees of the same species [46]. Differences were found between the physiological resin composition coming from a healthy tree and the pathological resin flowing from the bark of the injured tree. (Similar designations - a constitutive and induced resin.) Pathological resin consists substantially of terpenes and resin acids, is fat-free, after distilling turpentine it provides excellent resin and is also referred to as the callus resin [47]. The resin obtained by extraction from harvested wood cannot be also considered as physiological in origin, because the solvents used are not indifferent to the oleoresin and to its constituents and the resin obtained by extraction is chemically modified. From the chemical point of view, the oleoresin obtained from growing trees is, therefore, more acceptable and represents a more appropriate approach.

The importance of energy analysis of dendromass components, in this case the oleoresin, is not only important for obtaining information on living nature, but as well for its high content in some woods. Due to their high energy value, these findings play an important role, for example, in selecting such biochemical taxon of trees, which ensure the highest possible production of energy biomass already at the establishment of energy forest plantations [48, 49]. 


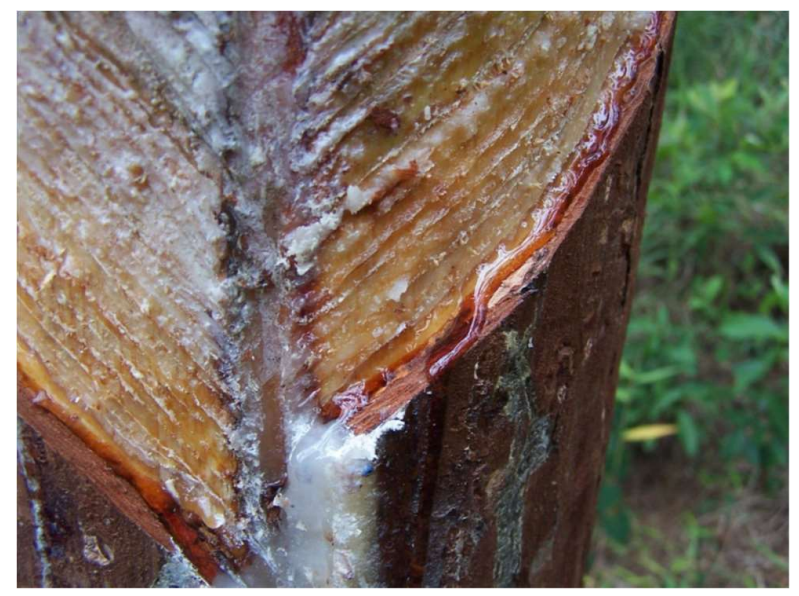

Figure 1. American pine resin tapping techniques (V-shaped streaks (2-3 mm wide). Cut into xylem. Source: $[48,49]$.

Generally, 4 pine resin tapping techniques are used all over the world. The most effective is the American method (Fig. 1, improved V-shaped) [50], often referred to as the Bark streak method [51].

Nowadays, it is well established that the tree resin properties depend on key factors, mainly on climate conditions $[52,53]$, genetic background and environmental effects [42, 54]. Additionally, quality and quantity of resin and its byproducts can be influenced by age [55], geographic origin [43], and different stresses, such as low fertility soils [56], drought [44,57], extreme temperatures [58-60], and hydrological impact [61]. Further, resin production can be modulated by resin-tapping methods [50], associated with chemical stimulation treatments [62].

Although the history of tapping and processing of tree resin go back to $18^{\text {th }}$ century, there are rare energy values such as the combustion heat and calorific value stated for a macroergic substance such as oleoresin. Lack or incompleteness of these findings prompted us to conduct the energy review of the resin of economically most important conifers in the Central European region - spruce (Picea abies (L.) H. Karst) and pine (Pinus sylvestris L.), and larch (Larix decidua Mill.) trees. The main goal of this work is to determine the combustion heat of the oleoresin of these trees and to compare them with those of further tree wood components. Knowing the energy levels of these substances is interesting because biomass currently forms the basis of renewable energy sources and forest ecosystem services in Central European conditions.

\section{Materials and Methods}

\subsection{Sampling material}

The resin samples were taken by the modified Streaking method from spruce (Picea abies (L.) H. Karst), pine (Pinus sylvestris L.), and larch (Larix decidua Mill.) trees growing on the Cernova research area (3,3 ha), nearby Ruzomberok (A: $49.101501 \mathrm{~N}, 19.236523 \mathrm{E}, \mathrm{B}: 49.100178 \mathrm{~N}, 19.236632 \mathrm{~N}, \mathrm{C}: 49.100344 \mathrm{~N}, 19.239303 \mathrm{E}, \mathrm{D}: 49.101986 \mathrm{~N}, 19.239519 \mathrm{E})$ approximately at an altitude of $490 \pm 90 \mathrm{~m}$ asl., transported to the laboratory and stored in a freezer prior to the energy determination analyses. The tree bark was cut with a groove knife to sapwood (modified V-shaped streak), later the resin flowing from there was collected by attached cups. The resin obtained by this way is not literally physiological resin. However, it is more suitable than that obtained from harvested timber by a chemical extraction.

To compare the energy of the resin obtained by the Streaking method, resin component from the pulp production, known as turpentine, was used. This is essentially a mixture of resins. The measured energy value of the resin was further compared with the basic constituents of the dendromass such as bleached and unbleached cellulose and turpentine. These wood constituents were obtained from Mondy SCP, Ltd., a pulp and paper complex in Ruzomberok.

\subsection{Assessment of energy - calorimetry}

Approximately $1.0 \mathrm{~g}$ of liquid samples was weighted on the scale Denver Instrument SI-234 with a precision of $0.0001 \mathrm{~g}$ and placed into a $3 \mathrm{ml}$ metal crucible. After weighing, determination of the combustion heat was accomplished in an adiabatic bomb calorimeter (Model IKA Calorimeter C400). The resin sample was completely incinerated at $3.0 \pm$ $0.3 \mathrm{MPa}$ under pure oxygen environment. The heat emitted during incineration was transferred to the calorimeter fluid, 
whereby the heat capacity for each calorimeter is specific. From the difference in temperature $(\Delta T)$ between the initial condition and the temperature of the calorimeter fluid after incineration, the level of energy released from the sample material as well as combustion heat was calculated by the respective equation [63]. At least one replicate determination was carried out for each resin sample.

\subsection{Statistical evaluation}

Table 1. Statistical parameter of combustion heat of tree resin $\left(\mathrm{MJ} \cdot \mathrm{kg}^{-1}\right)$.

\begin{tabular}{lccc}
\hline & Pine & Spruce & Larch \\
\hline Minimum & 36.00 & 34.60 & 36.30 \\
Maximum & 40.10 & 40.00 & 39.70 \\
Range & 4.10 & 5.40 & 3.40 \\
Mean & 38.60 & 38.37 & 38.33 \\
Stand. error & 0.30 & 0.35 & 0.23 \\
Stand. deviation & 1.30 & 1.53 & 0.99 \\
Variance & 1.70 & 2.33 & 0.97 \\
Skewness & -0.65 & -1.51 & -0.57 \\
Kurtosis & 0.52 & 2.05 & 0.52 \\
Number & 19.00 & 19.00 & 19.00 \\
\hline
\end{tabular}

The data determined were tested for normality, using the Kolmogorov-Smirnov test using the SPSS statistical packet. Normal distribution for the combustion heat data of pine and larch was confirmed by $p$-values of 0.141 and 0.200. In the spruce data, the first two values were outliers, and the data did not meet normality presumption ( $\mathrm{p}=0.026$ ). A significant difference between the combustion heats determined for pine, spruce and larch was not proved by the non-parametric Kruskal-Wallis test $(\mathrm{p}<0.509)$. Statistical parameters of combustion heat values for pine (Pinus sylvestris L.), spruce (Picea abies (L.) H. Karst) and larch (Larix decidua Mill.) are stated in Tab. 1.

\section{Results}

Renewable biomass resources studied in the past for energy purposes comprise a lot herbaceous and woody plants. In the composition of the wood, the main components account for $97-98 \%$ (saccharide: cellulose $49 \%$, hemicellulose $24 \%$ and aromatic: lignin 24\%) and the accompanying components 2-3\% (e.g. resin). This work focuses on forest tree species, especially on the tree resin.

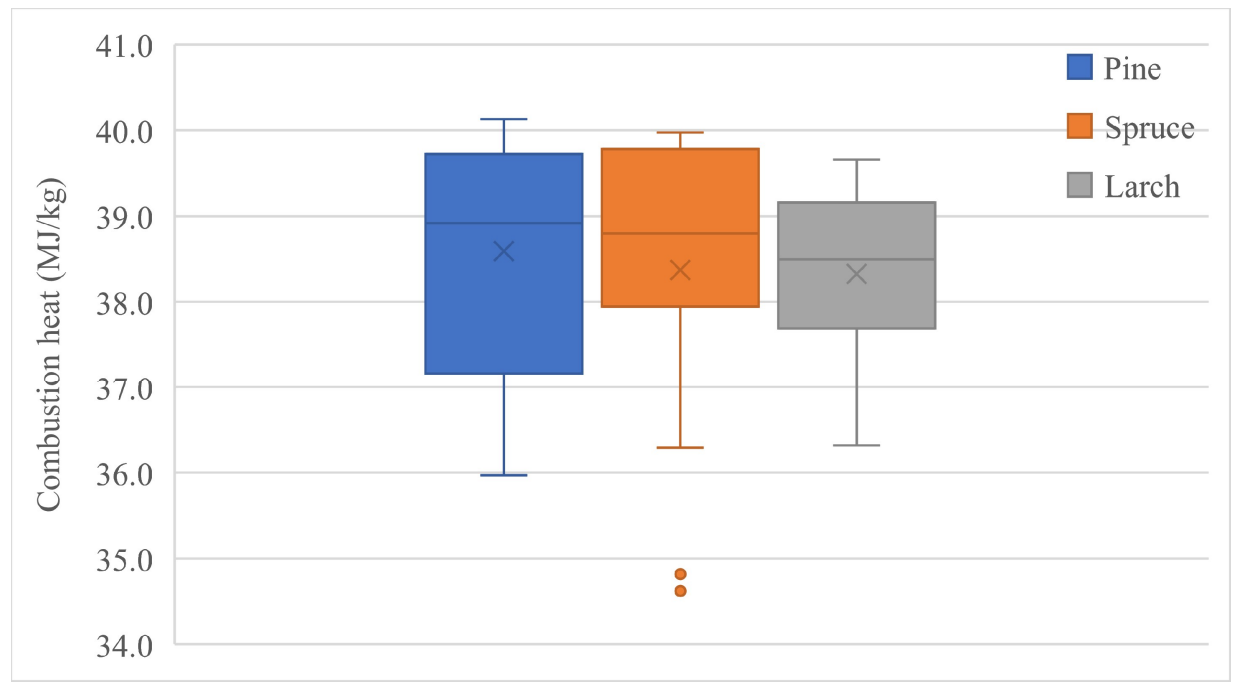

Figure 2. Resin combustion heat of pine, spruce and larch. $\mathrm{N}=19$. 
The results of the energy analysis are presented for the combustion heats of the resin from Pinus sylvestris L., Picea abies (L.) H. Karst and Larix decidua Mill. (Fig. 2) and as well as for pulp, an intermediate in wood production and for turpentine as a component of the resin (Tab. 2). For other components of tree biomass, energy parameters are relatively well known [37, 64]. Heating values of pine, spruce and larch are quite high and tree resin is probably the substance with the highest energy content of tree components in plants at all. The mean combustion heat of pine is $38.591 \pm 1.307$ MJ.kg-1 spruce $38.373 \pm 1.521 \mathrm{MJ} . \mathrm{kg}^{-1}$ and larch $38.326 \pm 0.975 \mathrm{MJ} . \mathrm{kg}^{-1}$. Difference between the combustion heats of pine, spruce and larch is statistically insignificant $(\mathrm{p}<0.509)$.

The resin energy values measured were further compared with cellulose associated with paper production and which can be supposed to be a by-product. Readings of bleached pulp (cellulose) produced by the Kraft sulphate process may serve as the energy reference standard for tree biomass. The mean combustion heat of bleached (17.319 \pm 0.025 MJ.kg-1) and unbleached pulp (15.955 $\pm 0.036{\left.\mathrm{MJ} . \mathrm{kg}^{-1}\right)}^{-}$(Tab. 2) are 2.2 and 2.4 times lower compared to the lowest value of investigated tree resin (larch $\left.38.326 \pm 0.975 \mathrm{MJ} . \mathrm{kg}^{-1}\right)$.

Table 2. Resin combustion heat of bleached and unbleached pulp, and turpentine.

\begin{tabular}{lcc}
\hline Component of wood & Combustion heat $\left({\left.\mathrm{MJ} . \mathrm{kg}^{-1}\right)}^{-1}\right.$ & Ash $(\%)$ \\
\hline Bleached pulp & $17.319 \pm 0.025$ & 1.29 \\
Unbleached pulp & $15.955 \pm 0.036$ & 8.21 \\
Turpentine & $39.773 \pm 0.027$ & 2.83 \\
\hline
\end{tabular}

The combustion heat of turpentine $\left(39.773 \pm 0.027 \mathrm{MJ} \cdot \mathrm{kg}^{-1}\right)$, constituent produced as a by-product at the sulphate technological procedure is 2.3 and 2.5 times higher than that of white and brown pulp. This figure is even slightly higher than that of tree resin and it may be due to the different representation of volatile components of turpentine (Tab. 3; Fig. 3).

Table 3. - Composition of turpentine.

\begin{tabular}{lc}
\hline Constituent & Content \\
& $(\%)$ \\
\hline Dimethylsulphide & 25.54 \\
Dimethyldisulphide & 0.14 \\
$\alpha$ - pinene & 36.28 \\
Camphene & 0.72 \\
$\beta$ - pinene & 9.74 \\
Myrcene & 0.15 \\
d-3 carene & 9.34 \\
P-cymene & 0.29 \\
D-limonene & 2.70 \\
$\alpha$-terpinene & 0.93 \\
$\Gamma$ - terpinene & 0.18 \\
Terpinolene & 0.94 \\
Unidentifiable & 3.95 \\
Unidentifiable (heavier than terpinolene) & 9.1 \\
\hline
\end{tabular}

Method: Gas Chromatograph - Agilent 7890A Yield and technical characteristics of the tapping operations.

The properties of oleoresin are determined considerably by the proportion of volatile monoterpenes. The ratio of volatile to non-volatile components affects the physical and defensive properties of oleoresin. The volatile and more fluid components of resin enable movement of the more viscous non-volatile components. The non-volatile di- and triterpenoid or phenolic components increase the viscosity and rate of crystallization of the oleoresin. These properties affect the rate of resin flow and the ability of the resin to trap and immobilize enemies or coat wounds in tree trunks, which has been considered a first line of tree defence [10].

In this work, the analysis of the representations of turpentine components was performed and the concentrations measured were compared to those in the oleoresin of Pinus sylvestris, L. (Fig. 3). The highest levels in turpentine were 


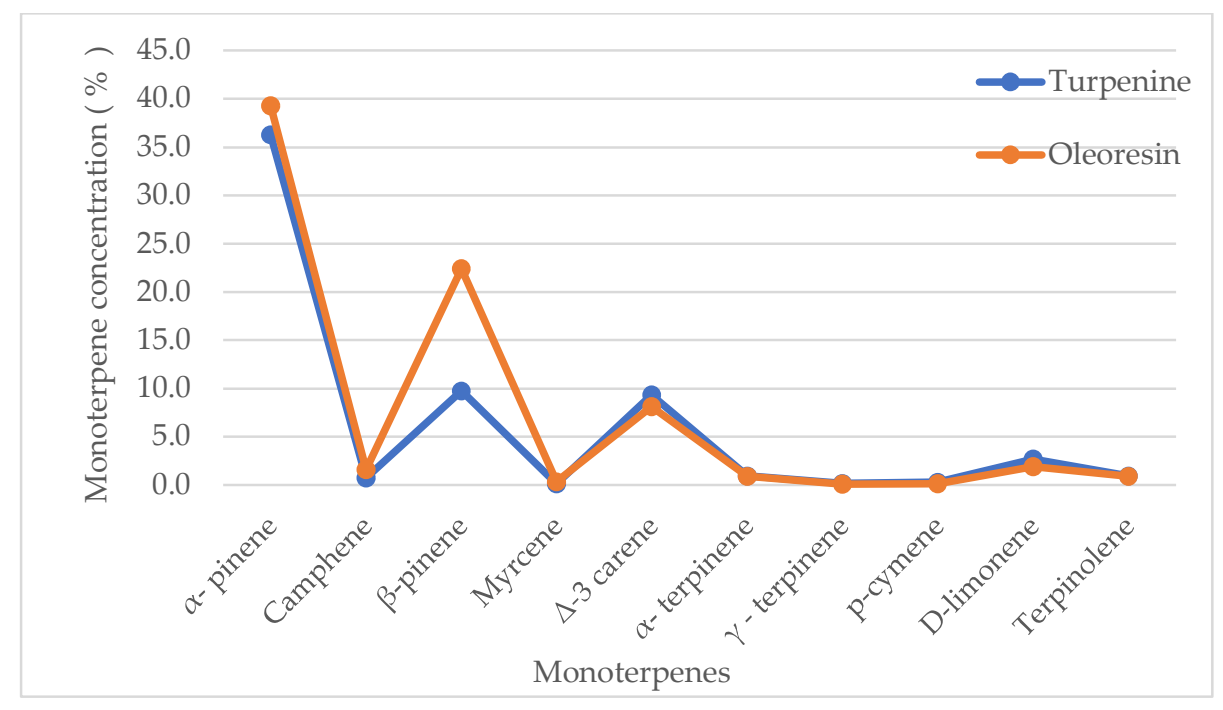

Figure 3. Monoterpene concentrations in turpentine and oleoresin of Pinus Sylvestris, L. (Oleoresin values were borrowed from [65])

recorded for $\alpha$ - and $\beta$-pinenes (together making up $46 \%$ of the total content), but still lower than that of oleoresin (62\%). $\Delta$-3-carene and D-limonene were in a range of 3-10\%. Further resin constituents observed were below $1 \%$ - Terpinolene, Camphene, $\alpha$ - and $\gamma$-terpinene, P-cymene, and Myrcene. Although turpentine is prepared by a distillation process, its composition is rather similar to that of the oleoresin of Pinus sylvestris L. [65]. A similar composition of monoterpenes was found in needles and cortical oleoresin [66]. While in needle the major constituent was $\beta$-pinene, in the latter $\alpha$ pinene. In general, the content of monoterpenes in needle oleoresin decrease from winter to summer while the concentration of sesquiterpenes increases. In cortical oleoresin, the case was vice-versa. This descending trend of monoterpene concentrations in needles was most likely caused by their ascending release into the atmosphere with increasing temperature up to the summer period. The monoterpene contents as main components of natural emission load have its own effect on the course of global warming.

Further, the combustion value of resin was compared to that of tree species. The combustion heat of tree wood irrespective of tree species ranges from 18.000 to $20.000 \mathrm{MJ} . \mathrm{kg}^{-1}$ [67]. Similar results were stated for softwood [38, 68]. The lowest value is for Eastern white cedar branches $\left(18.668 \mathrm{MJ}_{\mathrm{kg}}{ }^{-1}\right)$ and the highest one for Black spruce treetop (21.562 MJ.kg-1); a mean value of all softwood components is 20.178 MJ.kg-1. For a hardwood, this span is wider - the lowest value (17.230 MJ.kg-1) for Manitoba maple foliage and the highest one (2l.119 MJ.kg-1) for White birch foliage; a mean of all components is $19.146 \mathrm{MJ} \cdot \mathrm{kg}^{-1}$. Even a wider span of values is stated [69] in statistical summary of the calorific values of 402 species of wood of 246 genera and 66 species of bark of 33 genera, based primarily on literature surveys. The calorific values range from 15.584 to $23.723 \mathrm{MJ} . \mathrm{kg}^{-1}$ for hardwoods and from 18.608 to $28.447 \mathrm{MJ} . \mathrm{kg}^{-1}$ for softwoods. Except for the highest values for softwoods, the resin combustion heat is almost twice higher.

In the case of refined liquid hydrocarbon fuels such as petrol or diesel, the mean energy value of conifer resins is close to the lower end of the combustion heat range of diesel (about $41.900 \mathrm{MJ} \cdot \mathrm{kg}^{-1}$ ) and petrol (43.500 MJ.kg-1). However, the maximum measured value of pine resin combustion heat $\left(40.109 \mathrm{MJ} \cdot \mathrm{kg}^{-1}\right)$ is lower only by 5 per cent of its combustion heat $(1.8 \mathrm{MJ})$. High-calorific solid fuel such as coke achieves only $70 \%$ of the heating value measured for the pine resin. Similarly, a $2 / 3$ for a black coal (65\%) and only an $1 / 3$ for a brown coal $(36 \%)$.

\section{Discussion}

The use of renewable energy sources is becoming increasingly important in order, to achieve the changes required to address the impacts of global warming. In the context of current European Union policy, woody biomass is expected to be an important energy resource in a near future. Up to now tree biomass has been investigated mostly for energy utilization of tree body components such as branches and stumps of broadleaves and conifers [37, 68]. However, several studies have been specifically focused on the enhancement of fuel characteristic of woody biomass such as wood density, volatile matter, and calorific value of wood [70], the fertilization of Picea abies stands [71], landscaping and 
bioesthetic planning [72]. Further, individual constituents of tree resin such as rosin and turpentine have been studied [73-75]. However, only a limited number of studies have focused on a macroergic material such as tree resin.

The output of this paper revealed that the combustion heat of pine, spruce and larch equals to $38.591 \mathrm{MJ} . \mathrm{kg}^{-1}, 38.373$ MJ.kg-1 and 38.326 MJ.kg-1, respectively, the difference between figures determined is statistically insignificant ( $<<0.509)$. The analysis of the energy components of the wood biomass has shown that the combustion heat of oleoresin (Fig. 2) was higher than that of bleached cellulose (2.2-fold) and unbleached cellulose (2.4-fold). Only the calorific value of turpentine was higher by $4 \%$, but the percentage of turpentine in spruce wood is only $0.1-0.2 \%$. The resin content of the tree's wood is more than 10 times.

Table 4. Yield and technical characteristics of the tapping operations. The values are valid for pine tree.

\begin{tabular}{lcc}
\hline Location & Brazil & China \\
\hline Tapping ter & American & Chinese \\
\hline Density (trees/ha) & 800 & 700 \\
DBH (cm) & 25 & 15 \\
Season (months) & 9 & 5.6 \\
Years in production & $\sim 20$ & 5 to 7 \\
Yield per time (g/day) & 19.7 & 11.2 \\
Trees tapped per worker & 7,000 & 1,500 \\
Hectares tapped per worker & 8.75 & 2.18 \\
Metric tonnes produced per worker & 35 & 3 \\
Pine resin (kg/year) & 5 & 2 \\
\hline
\end{tabular}

Legend: Modified table [50].

Similar results, however showing large variation, were recorded by Howard [41] and Ivask [76]. While Howard [41] reported lower heating values in a range of 34.89-37.22 MJ.kg- for tree pine resin, Ivask [76] has recorded for spruce resin higher values $40.10 \pm 0.62 \mathrm{MJ} . \mathrm{kg}^{-1}$. These differences in energy values for tree resin can be explained by differences in the ratio of cellulose and lignin [41] and by a topographical aspect [77], an ecological aspect [78], a seasonal aspect [79], an environmental aspect, and naturally by the conditions and methods of determination. Variation in values [41] was large, as the samples were difficult to mix thoroughly and therefore not homogenous. The latter [76] investigated predominantly the influence of a seasonal aspect, as well as local and climatic conditions on the energy parameters of tree wood components. Spruce tree resin combustion heat was determined only in six samples and the author [76] has himself admitted that a random estimate of calorific values yields very little information.

Although oleoresin is obtained by tapping in small quantities, but it almost along the whole year and from a still living tree. The quantity and quality of the oleoresin is determined also by a tapping process. The first sampling of resin from pine trees began in the mid-19th century [80] and has continued so far. However, it is necessary to mention that since the '80s of the last century there was a decline in oleoresin sampling due to lower purchase prices. This decrease in price was caused by the advent of cheaper competing commodities produced from crude oil. However nowadays, oleoresins with high calorimetric values might be posed for a comeback in economies that utilize green biofuels and bioproducts from non-food feedstocks [81]. There are four methods of oleoresin tapping, the American way is the most effective and provides 2.5 times the yield of the Chinese one (Tab. 4). The largest quantities of resin have been tapped from the pine trees.

American method of sampling provides $5 \mathrm{~kg}$ of resin per year under optimal conditions. This amount fluctuates according to local conditions, for example in Portugal, this amount recorded was mostly half [82]. Some investigations have been carried out with the aim of assessing the economic viability of performing resin-tapping operations [21, 33, $34,35]$. However, the highest increase in extractive contents in Pinus elliottii biomass was achieved by using a $2 \%$ paraquat-cation stimulant [83]. In the low $152 \mathrm{~cm}$ bolt, there was an $884 \%$ rise of resin acids amounts and a $2360 \%$ for turpentine, for the whole stem it was $273 \%$ and $684 \%$ increases, respectively. By applying of a $2 \%$ paraquat-cation stimulant 
at the American way of tapping, the yield might be as much as $18.65 \mathrm{~kg}$ of oleoresin per a pine tree. Per hectare, it would be a total amount of $14,920 \mathrm{~kg}$ ( $575.78 \mathrm{GJ})$. Increasing resin production goes hand with hand with damage to the health status of sample trees.

Tapping, irrespective of the method employed, causes intensive wounds in the tree stems leading to wood deformation. Tapped trees compared to non-tapped ones for a tapping time period show a decrease in mean tree ring width by $14.1 \%$ (an average tree ring width of $2.41 \pm 0.85 \mathrm{~mm}$ was reduced to $2.07 \pm 0.7 \mathrm{~mm}$ ) and in late wood proportion by $6 \%$, respectively [84]. Decreases in the volume of the wood are visible, however, this damage is negligible compared to the energy that is stored in the tapped resin.

Due to its diverse possibilities of applications, the genus Pinus is considered as one of the most important commercial timber species [85]. Today it is well established that the resin properties depend mostly on factors such as genetic background and environmental effects [42, 54]. Its low technical requirements for planting [19] make Pinus one of the most suitable woody species for cultivating and restoring of marginal areas, as well as abandoned and degraded agricultural lands [86].

In the period 2015 - 2030 the incremental abandonment is expected to reach 4.2 Mill. ha net (approx. 280,000 ha per year on average) of agricultural land, bringing the total abandon land to 5.6 Mill. ha by 2030 (3\% of total agricultural land). Arable land is projected to account far the largest share of abandoned land (4.0 Mill. ha; $70 \%)$, followed by pasture (1.2 Mill. ha; $20 \%)$ and permanent crops (0.4 Mill. ha; 7\%). Nearly a quarter ( $\approx 1.38$ Mill. ha) of all agricultural abandonment in mountainous areas in the EU will probably occur [87]. Supposing that half of abandoned agricultural land in mountainous areas (700,000 ha) would be afforested and pine oleoresin would be tapped from an adult pine stand growing on this land. The pine oleoresin collected by the American way using a $2 \%$ paraquat-cation stimulant over one year would yield an energy of $403.044 \mathrm{PJ}$, which provides $0.82 \%$ of the fossil coal energy and $0.24 \%$ of total energy (160 -180 EJ) consumed worldwide in 2018. This energy represents more than 15,5 Mt Gt of coal, with each metric tonne of coal producing 1,700-1,800 $\mathrm{m}^{3}$ of $\mathrm{CO}_{2}$, thus exacerbating the problem of global warming. [88]. If this coal would be replaced by tapped resin in combustion process, atmospheric load would be reduced by $27.1 \mathrm{Gm}^{3} \mathrm{CO}_{2}$, i.e. $53.7 \mathrm{Mt}$, as its origin is not fossil (Tab. 5).

Table 5 Resin and carbon dioxide quantities associated with a 700,000 hectares pine forest stand.

\begin{tabular}{cccccc}
\hline Area & \multicolumn{2}{c}{$\begin{array}{l}\text { Resin tapped } \\
\text { over one year }\end{array}$} & $\begin{array}{c}\mathrm{C} \text { sequestered } \\
\text { by pine trees }\end{array}$ & \multicolumn{2}{c}{$\begin{array}{c}\mathrm{CO}_{2} \text { released from coal } \\
\text { (Equivalent of resin amount) }\end{array}$} \\
\hline$(\mathrm{ha})$ & $(\mathrm{Mt})$ & $\mathrm{Q}(\mathrm{PJ})$ & $(\mathrm{Mt})$ & $\left(\mathrm{Gm}^{3}\right)$ & $(\mathrm{Mt})$ \\
\hline 700000 & 10.444 & 403.044 & 1,179 & 27.128 & 53.700 \\
\hline
\end{tabular}

Legend: 4.320 $\mathrm{Mt} \mathrm{CO}_{2}$ is equivalent to $1.179 \mathrm{Mt} \mathrm{C}$; $\mathrm{Q} \mathrm{co} 2=1.98 \mathrm{~kg} \mathrm{~m}^{-3} ; \mathrm{m}_{\text {coal }}=\left(\frac{\text { Qresin }}{\text { Qcoal }}\right) * 10.444=15,5(\mathrm{Mt})$

Further, forests were also recognized for other services such as the ability to store carbon and mitigate the impacts of climate change [89]. Forest plantations are beneficial in mitigating climate change and reducing airborne emissions only through stringent management. The 700,000 ha Pinus sylvestris plantation with a net ecosystem exchange (NEE) rate of $1.684 \mathrm{tC} \mathrm{ha}^{-1} \mathrm{yr}^{-1}$ sequesters 1,179 Mt of carbon per year, resp. 4,320 Mt CO . The NEE value is controlled by numerous factors, the most pronounced by latitude [90]. A mean NEE value was calculated from 3 geographic places with an increasing latitude: from northern Spain (lat $42^{\circ} \mathrm{N}$ ) $-1.47 \pm 0.23 \mathrm{tC} \mathrm{ha}^{-1} \mathrm{yr}^{-1}$, [91] to Netherlands (lat $52^{\circ} \mathrm{N}$ ) -2.0

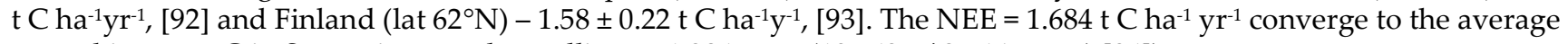
annual increase $C$ in Scots pine stand equalling to $1.234 \mathrm{t} \mathrm{yr}^{-1}$ (105.42 $\mathrm{t} / 85.46$ years) [94]).

Albeit the aforementioned example of afforestation consists only in a theoretical level, it reveals the possibilities of oleoresin utilization in the environmental field. All constituents of biomass are photosynthesized in plant leaves from $\mathrm{CO}_{2}$, water and absorbed sunny energy. A specific feature of the biomass is that its combustion produces the same amount of this greenhouse gas that was absorbed during photosynthesis. Biomass is neutral for $\mathrm{CO}_{2}$ emission. Establishment and management of forests as a source of oleoresin also support the removal and storage of $\mathrm{CO}_{2}$ from the atmosphere and offset the increase in anthropogenic emissions of greenhouse gasses (GHG) and consequently reduce the rate of global warming and mitigate the impacts of climate change [65, 89, 95-98]. Plantation system is a good means of climate change mitigation [99, 100].

To keep the Paris Agreement relating to the global temperature rise below $2{ }^{\circ} \mathrm{C}$ above pre-industrial levels, the world will need to rely more on bioenergy with carbon capture and storage technology (BECCS) [101]. That means conversion of the current fossil-fuel-base system to a lower-carbon energy system in which bioenergy plays a more 
important role in reducing carbon levels. Only under stringent management, forest plantations can be beneficial in reducing airborne emissions and mitigating climate change. Feedstock supply of dedicated bioenergy crop estimates varies between 1.7 and $12.8 \mathrm{EJ} \mathrm{yr}^{-1}$ by 2030. In addition, agricultural residues and forestry residues can potentially add to this 3.1-3 .9 $\mathrm{EJ} \mathrm{yr}^{-1}$ and 1.4-5.4 $\mathrm{EJ} \mathrm{yr}^{-1}$, respectively [102]. Energy-efficient feedstocks must be used to meet this high energy demand. There is a need to do an economic analysis which generation feedstock is the least costly for this purpose.

Generally, according to the essence of the production processes, feedstocks are divided to the first, second and third generation [102-106]. The first-generation biofuels are derived from edible crops. However, the production of fuel from food crops comes with large societal, environmental and economic concerns [107], mainly because of extensive use of productive land and generally intensive use of resource (fertilization and irrigation; [108]. Second-generation biofuels (also known as advanced biofuels) are produced from lignocellulosic materials obtained from the cell walls of plants, which comprises the majority all plant biomass [107] and around 75\% of the cell wall portion is composed of polysaccharides [109]. The production of these feedstocks does not necessarily compete with that of food crops. Oleoresin by its lignocellulosic nature can be assigned to the second generation of feedstocks. Third-generation feedstocks are produced from algae, sewage sludge, and municipal solid wastes (this is omitted) [105]. The prices of these feedstock generations differ. First generation feedstock supply is supposed to be available at production costs of 5-15 $€ \mathrm{GJ}^{-1} \mathrm{com}^{-}$ pared to 1.5-4.5€ $\mathrm{GJ}^{-1}$ for second generation feedstocks [102]. Approximately, the production cost of first-generation feedstocks is triple that of the second-generation ones. This difference is slightly smaller between the cost of residues in agriculture and forestry (1-7 € GJ-1 and 2-4€ GJ-1, respectively).

For the period 2008-2011, production cost of oleoresin was nearly the double that of lignocellulosic crops $0.2-0.4 \$$ $\mathrm{kg}^{-1} \equiv 4.6-9.2 € \mathrm{GJ}^{-1}[110]$. Brazilian association of resin tapping companies (ARESB) [111] have stated even higher average price $0.47 \$ \mathrm{~kg}^{-1}$. However, when oleoresin tapping is carried out by the American tapping method with the application of $2 \%$ paraquat-cationic stimulant, the production cost was significantly reduced. If we take into account the ratio be-

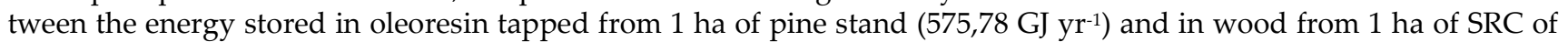
willow (172 GJ $\left.\mathrm{yr}^{-1}\right)$, the oleoresin production per unit amount is the cheapest 1.3-2.75 $€ \mathrm{GJ}^{-1}$. Further investigation is needed to demonstrate this, as this is pioneering research.

Table 6. Comparison of energy values of renewable energy sources.

\begin{tabular}{lcccc}
\hline \multirow{2}{*}{ Species } & Yield & Heating value & \multicolumn{2}{c}{ Energy per hectare } \\
\cline { 2 - 5 } & $(\mathrm{t})$ & $\left(\mathrm{MJ} \mathrm{kg}^{-1}\right)$ & $(\mathrm{GJ})$ & $(\mathrm{MWh})$ \\
\hline Feeding $^{\mathrm{a})}$ sorrel & 10.0 & 16.00 & 160.00 & 44.44 \\
Common $^{\mathrm{b})}$ reed & 12.7 & 17.45 & 221.60 & 61.56 \\
Amaranth $^{\mathrm{c})}$ & 32.0 & 11.00 & 352.00 & 97.78 \\
Pine resin $^{\mathrm{d})}$ & 14.9 & 38.59 & 575.80 & 159.94 \\
\hline
\end{tabular}

Legend: a) a hybrid of Rumex patientia L. (maternal line) and Rumex tianschanicu (paternal line) species [112];

b) Phragmites australis (Cav.) Trin. [113]; c) Miscanthus gigantheus [114, 115] d) Pinus sylvestris

The use of tree biomass is gaining in importance as part of mitigating the impact of climate change. If properly managed, biomass plantations can really increase habitat biodiversity [116, 117] and soil qualities [117, 118], at least on previously degraded land. This also increases the feasibility of extracting tree resins as a renewable energy source, especially when timber harvesting in the forest ecosystem is not problem-free. Biofuels are a potential low-carbon energy source, but whether biofuels offer carbon savings depends on how they are processed [100, 119-123].

The tree resin was proved to be an excellent renewable energy source that has not yet been used for this purpose. Compared to the previously investigated energy sources, the resin has the highest energy content per hectare (Tab. 6). The production of oleoresin is not the primary goal, but with afforestation, the volume of the greenhouse gas $\mathrm{CO}_{2} \mathrm{will}$ be reduced, and consequently the rate of global warming will also be dampened. Afforestation associated with conversion of marginal agricultural or forestry lands to purpose-grown crops is an important practice used for lowering the rise in atmospheric $\mathrm{CO}_{2}$ concentration due to forest ability to fix carbon in the tree biomass and in the soil [65, 124, 125]. With rising global temperatures and atmospheric $\mathrm{CO}_{2}$ concentrations, plantation forests due to their rapid initial growth have enhanced their potential to sequester carbon. So, forests constitute a large carbon sink [126, 127]. The shift in the location of total ecosystem $\mathrm{C}$ from below- to aboveground and the decline in soil organic $\mathrm{C}$ results in long-term $\mathrm{C}$ storage in a forest stand [128] However, intensive deforestation would imply a decrease of approximately $66 \%$ of the bulk $\mathrm{CO}_{2}$ fixed [126]. Nutrient-poor forest soils also limit this asset. 
Where wood reduction in forest requires removal of woody biomass, utilizing it for power generation reduces overall emissions by $98 \%$ in comparison with slash pile burning [129]. Energy production in the forest is more environmentally friendly. For example, regrowth energy in a forest stand generated from wood leads to production of 0.057 metric tonne of $\mathrm{CO}_{2 \text { e }}$ per MWh compared with the average US rate of 0.60 metric tonne of $\mathrm{CO}_{2 e}$ per $\mathrm{MWh}$ [130]. Striking relations are also between the annual amounts of the carbon sequestered by pine tree biomass, the resin tapped from pine trees by the American methods and the carbon dioxide released from coal having the same energy content as the tapped resin. The lowest amount was recorded for carbon sequestered by tree biomass. The resin extracted was 9-times and the released $\mathrm{CO}_{2} 45$-times the quantity of the carbon sequestered (Tab. 5). That means one tonne of oleoresin corresponds approximately to 5 tonnes of $\mathrm{CO}_{2}$. If the oleoresin was as a renewable energy source burned instead of coal, emission load in the atmosphere would be reduced roughly by 5 tonnes anthropogenic $\mathrm{CO}_{2}$. (This is valid providing $\mathrm{CO}_{2}$ generated from resin is environmentally neutral.) Furthermore, 0.113 tonne of $\mathrm{CO}_{2}$ was sequestrated by tree biomass during the tapping process.

While mitigation action in the forest sector has been widely promoted and assessed, the use of forest products in mitigation has received little emphasis [131]. Considering the afforestation, reforestation, forest management and wood products, for many countries the forest sector can offer mitigation options that are more time and cost effective than options in other sectors [127]. The global forest restoration target proposed by [132] of 1 billion ha (defined as $>10 \%$ tree cover) is undoubtedly achievable under the current climate. This clearly points out that there is enough free land as well as the need to mitigate and suppress a climate change by afforestation [100]. Reversing the loss of biomass stocks in the world's natural forests would correspond to a REDD+ (Reducing Emissions from Deforestation and Forest Degradation) mitigation potential of about $4 \mathrm{Gt} \mathrm{CO} 2$ per year from avoided deforestation and $1 \mathrm{Gt}^{\mathrm{CO}_{2}}$ per year from avoided forest degradation [133].

The limited use of forests and forest products in mitigating climate change is associated with natural emissions of volatile organic components (VOC) released into the air. Forest trees are known to contain numerous VOC including isoprene, mono- and sesquiterpenes and other compounds which may be widely distributed throughout plant organs. While conifers are the source of terpene emissions, isoprene is emitted mainly by broad-leaved trees [134]. There are also some exceptions. Coniferous trees are known to emit mainly monoterpenes such as $\alpha$ - and $\beta$-pinene, and others depending on the emitting species. Among the coniferous trees, Norway spruce (Picea abies) is the most abundant one (67\%), emitting $\alpha$-pinene, $\beta$-pinene and limonene [135]. Scots pine (Pinus sylvestris) emits $\alpha$-pinene, limonene, $\beta$-pinene, $\beta$-phellandrene and camphene [136]. All these compounds are constituents of the tree resin. The process of tree resin tapping decreases the $C$ pool in tree resin canals. As a result, VOC emissions into the atmosphere are pushed down. At the same time, it is necessary to note that monoterpene emissions do not have the same significance as those of anthropogenic origin. At $35^{\circ} \mathrm{C}, \alpha$ - and $\beta$-pinene were emitted in the largest quantities $\left(4.46\right.$ and $\left.3.44 \mu \mathrm{g} \mathrm{C} \mathrm{g} \mathrm{dry} \mathrm{weight} \mathrm{g}^{-1}\right)$, whereas limonene, myrcene, and phellandrene were only minor contributors to the total emissions. Approximately $0.4 \%$ of the carbon fixed daily in photosynthesis is lost through monoterpene volatilization [137]. Forest ecosystem has got the capacity of storing up to $263.13 \mathrm{t} \mathrm{ha}^{-1} \mathrm{C}$, assisting in mitigating climatic change by sequestrating $964.13 \mathrm{tha}^{-1} \mathrm{of} \mathrm{CO}_{2}$ equivalent, indicating that forests are an important $C$ sink [97]. Because the sequestration process is controlled by local and climatic conditions, the fertility of the soil, etc., the individual research results may vary $[22,138,139,140]$. Generally, one tonne of forest tree woody biomass sequestrates annually 1.429 tonnes $\mathrm{CO}_{2}$ from the atmosphere (a mathematical model; multiplied by $0.65 \times 0.5 \times 1.2 \times 3.664)$.

An establishment of tree stands is rather complex activities. Prior to afforestation, the model solution must be evaluated. Its complexity and scientific level depend on the climatic and terrain conditions of the model area [2, 141] and on the soil preparation by silvicultural practices [138]. The tree oleoresin can be an important renewable energy source in reducing the $\mathrm{CO}_{2}$ content in the atmosphere and a means of mitigating climate change. The oleoresin tapped from 1 ha $(575.78 \mathrm{GJ})$ yields 75 times energy needed to establish a 1 ha energy forest stand (7660 MJ ha-1, scenario III.) [142]. There is a need to find the best way of processing and application of the oleoresin for energy purposes. For example, utilization for thermal energy or propellants $[65,143,144]$.

\section{Conclusions}

This paper has focused on research the energy value (calorific or heating value) of some components of the tree biomass of pine, spruce and larch. Energy parameters of trees examined were determined by the calorimetry method. The components of wood pulp (bleached and unbleached) and turpentine were obtained from the pulp and paper processing plant Mondi SCP (Slovak Cellulose Paper mill), Ltd. in Ruzomberok. Samples of the tree resin were taken from the "V" shaped wound carved in the bark of the trees growing on the Cernova research stand nearby Ruzomberok. The

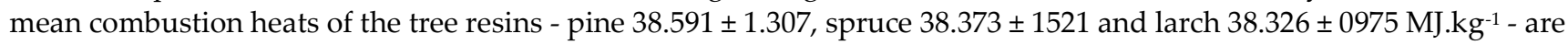
not statistically different from each other. However, these values are double the heating value of forest tree species wood and its components. 
Reading of bleached pulp (cellulose) produced by the Kraft sulphate process is supposed to be the reference standard for tree biomass. Average combustion heat bleached (17.319 $\left.\pm 0.025 \mathrm{MJ} . \mathrm{kg}^{-1}\right)$ and unbleached $(15.955 \pm 0.036 \mathrm{MJ} . \mathrm{kg}$ $\left.{ }^{1}\right)$ pulps are 2.2 and 2.4 times lower than those of investigated tree resin samples. The highest energy value was recorded for turpentine $39.773 \pm 0.027 \mathrm{MJ} . \mathrm{kg}^{-1}$, but its technical processing is considerably more complicated than that of the resin.

The quality and quantity of oleoresin is influenced by a way of tapping. The best is American methods providing $5 \mathrm{~kg}$ of oleoresin per tree over one year. However, by using the paraquat-cation stimulant this amount was enhanced to $18.65 \mathrm{~kg}$ of oleoresin per tree over a year, thus a 1 ha pine stand provides $14,920 \mathrm{~kg}$.

The tree resin was proved to be an excellent renewable energy source that has not yet been used for this purpose. Compared to the previously investigated energy source - Feeding sorrel $160 \mathrm{GJ} \mathrm{ha}^{-1}$, Common reed $221.6 \mathrm{GJ} \mathrm{ha}^{-1}$, Amaranth - 352.0 GJ ha-1, pine resin - 575.8 GJ ha-1 has got the highest energy content per hectare.

A production price of oleoresin was compared to other feedstocks. The production cost of first-generation feedstocks is triple that of the second-generation ones (5-15€ GJ-1 compared to $1.5-4.5 € \mathrm{GJ}^{-1}$ ). When using $2 \%-$ paraquat cation stimulant the production cost of oleoresin is the cheapest $1.3-2.75 €$.

The potential contribution of forest expansion to the sequestration of carbon and the utilization of renewable forest resources are well known. The tapping of resin and the expansion of its industrial uses can further enhance the carbon sequestration potential of forest resources and widen the forest ecosystem services. One ha forest stand can sequestrate

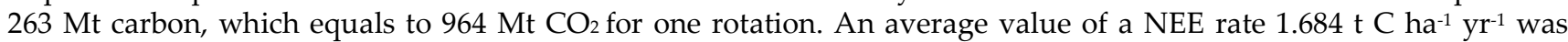
calculated from 3 geographic places (lat. from $42^{\circ} \mathrm{N}$ to $62^{\circ} \mathrm{N}$ ). If one tonne of oleoresin was burned instead of energy equivalent amount of coal, the atmosphere would be spare for more than $5 \mathrm{Mt} \mathrm{CO}_{2}$.

Tree oleoresin as a macroergic substance is approaching to the heating parameters of liquid hydrocarbon fuels such as oil and petroleum products. Therefore, oleoresin can play an important role in supersession of fossil fuels. Resin quantity and quality might be control by selecting suitable tree-taxa of high oleoresin content or increasing its energy content in a tree by applying a suitable stimulant. The product of this work is to be the cultivation of energy-modified biomass, a revolutionary shift in the production of renewable energy sources.

Acknowledgment: This paper is the result of the project VEGA no. 2/0013/17. The role of ecosystem services in support of landscape conservation under the global change.

\section{References}

[1] Warburg, C.T.; King'ondu, C.K. Energy characteristics of five indigenous tree species at Kitulangalo Forest Reserve in Morogoro, Tanzania. Int. J. Renew. Energy Res. 2014, 4, 1078-084.

[2] Constanza, J.K.; Abt, R.C.; McKerrow, A.J.; Collazo, J.A. Bioenergy production and forest landscape change in the southeastern United States. GCB Bioenergy 2017, 9, 924-939.

[3] Johnson, J.M.; Coleman, M.D.; Gesch, R.; Jaradat, A.; Mitchell, R.; Reicosky, D. Wilhelm, W.W. Biomass-bioenergy crops in the United States: A changing paradigm. Am. J. Plant. Sci. Biotechnol. 2007, 1, 1-28.

[4] Franceschi, V.R.; Krokene, P.; Christiansen, E.; Krekling, T. Anatomical and chemical defences of conifer bark against bark beetles and other pests. New Phytol. 2000, 167, 353-376.

[5] Wallin, K.F.; Raffa, K.F. Effects of folivory on subcortical plant defenses: Can defense theories predict interguild processes? Ecology 2001, 82, 1387-1400.

[6] Fischer, M.J.; Waring, K.M.; Forstetter, R.W. The resin composition of ponderosa pine (Pinus ponderosa) attacked by the round headed pine beetle (Dendroctonus adjunctus) (Coleoptera: Curculionidae, Scolytinae). In: Conference Proceeding (2008) Flagstaff AZ, Proc. RMRS-P-5, USDA FS 2008, pp. 178-182.

[7] Raffa, K.F.; Aukema, B.H.; Bentz, B.J.; Carroll, A.L.; Hicke, J.A.; Turner, M.G.; Romme, W.H. Cross-scale drivers of natural disturbances prone to anthropogenic amplification: the dynamics of bark beetle eruptions. BioScience 2008, 58, 501-517.

[8] Wang, J.; Chen, Y.P.; Yao, K.; Wilbon, P.A.; Zhang, W.; Ren, L. et al. Robust antimicrobial compounds and polymers derived from natural resin acids. Chem Commun. 2012, 48, 916-918.

[9] Gottlieb, O.R. Phytochemicals: differentiation and function. Phytochemistry 1990, 29, 1715-1724.

[10] Langenheim, J.H. Chemistry, Evolution, Ecology, Ethnobotany. Timber Press Cambridge, 2003, 612p.

[11] Nascimento, M.S.; Santana, A.L.; Maranhao, C.A.; Oliveira, L.S.; and Biebe, L. Phenolic extractives and natural resistance of wood. In Biodegradation - Life of Science, Edited by Chamy, R.; and Rosenkranz, F.; Chapter 13, 2013, pp.349-370. ISBN 978-953-51-1154-2

[12] Mirov, N. Composition of gum turpentines of pines. Tech. Bull. 1239, USDA FS 1961, 158p.

[13] Langenheim, J.H. Plant Resins. Am. Sci. 1990, 78, 16-24.

[14] Smith, R H. Xylem Monoterpenes of Pines: Distribution, Variation, Genetics, Function. General Technical Report PSWGTR- 177. Albany, CA: Pacific Southwest Research Station, USDA FS 2000, 454p. doi: https://doi.org/10.2737/PSW-GTR-177 
[15] Zwenger, S.; Basu, C. Plant terpenoids: applications and future potentials. Microbiol. Mol. Biol. Rev. 2008, 3, 1-7.

[16] Silvestre, A.J.D.; and Gandini, A. Terpenes: major sources, properties and application. In: Belgacem, M.M.; Gandidi, A. Monomers, polymers and composite from renewable resources. Elsevier Ltd. Amsterdam, First edition, 2008, 552p. ISBN 978-008-045316-3

[17] Smith, R.H. Monoterpenes of ponderosa pine xylem resin in Western United States, Forest Service, United State Department of Agriculture, Tech. Bull. no. 1532 1977, 48p.

[18] Leonhardt, S.D.; Blüthgen, N.; Schmitt, T. Tree resin composition, collection behaviour and selective filters shape chemical profiles of tropical bees (Apidae: Meliponini), PloS One 2011, 6(8), e23445. https://doi.org/10.1371/journal.pone.0023445

[19] Bohlmann, J.; and Keeling, C.I. Terpenoid biomaterials. Plant J. 2008, 54, 656-669.

[20] Rezzi, S.; Bighelli. A.; Castola, V.; Casanova, J. Composition and chemical variability of the oleoresin of Pinus nigra ssp. Laricio from Corsica. Ind. Crop. Prod. 2005, 21, 71-79.

[21] Jantam, I.; and Ahmad, A.S. Oleoresins of three Pinus species from Malaysian pine plantations. ASEAN Review of Biodiversity and Environmental Conservation, 1999. 1-9p. Available on: https:/www.researchgate.net/publication/238101480_Oleoresins_of_Three_Pinus_Species_from_Malaysian_Pine_Plantations (accessed on 3. November 2020)

[22] Lee, H.J.; Ravn, M.M.; and Coates, R.M. Synthesis and characterization of abietadiene, levopimaradiene, palustradiene, and neoabietadiene: hydrocarbon precursors of the abietane diterpene resin acids. Tetrahedron 2001, 57, 6155-6167.

[23] Mandaogade, P.; Satturwar, P.M.; Fulzele, S.V.; Gogte, B.B.; and Dorle, A.K. Rosin derivatives: novel film forming materials for controlled drug delivery. React. Funct. Polym. 2002, 50, 233-242.

[24] Swift, K.A.D. Catalytic transformations of the major terpene feedstocks. Top. Cat. 2004, 27, 143-155.

[25] McMorn, P.; Roberts, G.; and Hutchings, G.J. Oxidation of $\alpha$-pinene to verbenone using silica-titania co-gel catalyst. Catal. let. 2000, 67, 203-206.

[26] Gillette, N.E.; Hansen, E.M.; Mehmel, C.J.; Mori, S.R.; Webster, J.N.; Erbilgin, N.; Wood, D.L. Area-wide application of verbenone-releasing flakes reduces mortality of white bark pine Pinus albicaulis caused by the mountain pine beetle Dendroctonus ponderosae. Agric. For. Entomol. 2012, 14, 367-375.

[27] Mercier, B.; Prost, J.; and Prost, M. The essential oil of turpentine and its major volatile fraction ( $\alpha$ - and $\exists$-pinenes): a review. Int. J. Occup. Med. Environ. Health 2009, 22, 331-342.

[28] Adams, T.B.; Gavin, C.L.; McGowen, M.M.; Waddell, W.J.; Cohen, S.M.; Feron, V.J. et al. The FEMA GRAS assessment of aliphatic and aromatic terpene hydrocarbons used as flavour ingredients. Food Chem. Toxicol. 2011, 49, 2471-2494.

[29] Limberger, R.P.; Schuh, R.S.; and Henriques, A.T. Pine terpene biotransformation. 2012, pp. 107-126. In Fett-Neto AG, and Rodrigues-Corrêa KCS eds. Pine resin: biology, chemistry and applications. ISBN: 978-81-308-0493-4.

[30] Silva, A.C.R.; Lopes, P.M.; Azevedo, M.M.B.; Costa, D.C.M.; Alviano, C.S.; and Alviano, D.S. Biological activities of $\alpha$-pinene and $\beta$-pinene enantiomers. Molecules 2012, 17, 6305-6316.

[31] Macchioni, F.; Cioni, P.L.; Flamini, G.; Morelli, I.; Maccioni, S.; and Ansaldi, M. Chemical composition of essential oils from needles, branches and cones of Pinus pinea, P. halepensis, P. pinaster and P. nigra from central Italy. Flavour. Fragr. J. 2003, 18, 139-143.

[32] Burdock, G.A.; and Carabin, I.G. Safety assessment of Ylang-Ylang (Cananga spp.) as a food ingredient. Food Chem. Toxicol. $2008,46,433-445$.

[33] Tümen, I.; and Reunanen, M.A.; Comparative study on turpentine oils of oleoresins of Pinus sylvestris L. from three districts of Denizli. Rec. Nat. Prod. 2010, 4, 4, 224-229.

[34] Teshome, T. Analysis of resin and turpentine oil constituents of Pinus patula grown in Ethiopia. Ed-JRIF 3 2011, 3, 1, 38-48.

[35] Bublinec, E.; Kuklová, M.; Oszlányi, J. Fytometria a distribúcia energie v bukových ekosystémoch = Phytometry and energy distribution in beech ecosystems. In Buk a bukové ekosystémy Slovenska. - Bratislava: VEDA, vydavatel’stvo SAV 2011, 289327. ISBN 978-80-224-1192-9.

[36] Liu, M.H.; Yi, L.T. Combustibility of fresh leaves of 26 forest species in China. J. Trop. For. Sci. 2013,_25(4), 528-536.

[37] Aniszewska, M.; Gendek, A. Comparison of heat of combustion and calorific value of the cones and wood of selected forest tree species. Lesne Prace Badawcze. For. Res. Pap. 2014, 75, 3, 231-236.

[38] Álvarez-Álvarez, P.; Pizarro, C.; Barrio-Anta, M.; Cámara-Obregón, A.; Bueno, J.L.M.; Ávarez, A.; et al. Evaluation of tree species for biomass energy production in Northwest Spain. Forests 2018, 9, 160. doi:10 3390/19040160.

[39] Telmo, C.; Lousada, J.; Moreira, N. Proximate analysis, backwards, stepwise regression between gross calorific value, ultimate and chemical analysis of wood. Bioresour. Technol. 2010, 101, 3808-3815.

[40] Francescato, V.; Antonini, E.; Bergomi, L.Z. Wood Fuels Handbook. AIEL-Italian Agroforestry Energy Association, Agripolis; Food and Agriculture Organization: Rome, Italy 2008, p. 83.

[41] Howard, E.T. Heat of combustion of various southern pine materials. Wood Sci. 1972, 5, 194-197

[42] Aguiar, A.V.; Shimizu, J.Y.; Sousa, V.A.; Resende, M.D.V.; Freitas, M.L.M.; Moraes M.L.T.; Sebbenn, A.M. Genetics of oleoresin production with focus on Brazilian planted forests. 2012, p. 87-106. In: Fett-Neto, A.G.; Rodrigues-Corrêa, K.C.S. eds. Pine resin: biology, chemistry and applications. ISBN: 978-81-308-0493-4. 
[43] Lachowicz, H.; Sajdak, M; Paschalis-Jakubowicz, P.; Cichy, W.; Wojtan, R.; Witczak, M. The influence of location, tree age and forest habitat type on basic fuel properties of wood of the Silver birch (Betula pendula Roth.) in Poland. Bioenerg. Res. 2018, 11(3), 638-651.

[44] Turtola, S.; Manninen, A.M.; Rikala, R.; and Kainulainen, P. Drought stress alters the concentration of wood terpenoids in Scots pine and Norway spruce seedlings. J. Chem. Ecol. 2003, 29, 1991-1995.

[45] Ferreira, A.G.; Fior, C.S.; and Gualtieri, S.C.J. Oleoresin yield of Pinus elliottii Engelm seedlings. Braz. J. Plant Physiol. 2011, 23, 313-316.

[46] Blažej, A.; Košík, M. Fytomasa ako chemická surovina (Phytomass as a chemical resource). Bratislava: Veda vydavatel'stvo SAV 1985,404 p.

[47] Holmbom, T.; Reunanen, M.; Fardim, P. Composition of callus resin of Norway spruce, Scots pine, European Larch and Douglas fir. Holzforschung 2008, 62, 417-422.

[48] Santo, A.M.; Vasconcelos, T.; Mateus, E.; Farrall, M.H.; Gomes da Silva, M.D.R.; et al. Characterization of the volatile fraction emitted by phloems of four pinus species by solid-phase microextraction and gas chromatography-mass spectrometry. $J$. Chromathogr. A 2006, 1-2, 191-198.

[49] Marques, F.A.; Frensch, G.; Zaleski, S.R.M.; Nogata, N.; Maia, B.H.L.N.S.; Lazzari, S.M.N.; Lenz, C.A.; and Corrêa, G. Differentiation of five pine species cultivated in Brazil based on chemometric analysis of their volatiles identified by gas chromatography-mass spectrometry. 2012. In: Rodrigues-Corrêa, Lima, Fett-Neto, Food Energy Secur. 2012, 1, 2, 81-93.

[50] Cunningham, A. Pine resin tapping techniques used around the world. 1-8. In: Fett-Neto AG, Rodrigues-Corrêa CS. Pine Resin: Biology, chemistry and Applications 2012, eds. Pine resin: biology, chemistry and applications. ISBN: 978-81-308-0493-4.

[51] Rodrigues-Corrêa, K.L.S.; Lima, J.C.; Fett-Neto, A.G. Oleoresins from Pine: Production and industrial uses. In: Ramarat, K. Mérillon, J.M (eds.) Natural Products, Springer Berlin Heidelberg 2013, pp. 4037-4060.

[52] Juntunen, V.; and Neuvonen, S. Natural regeneration of Scots pine and Norway spruce close to the timberline in northern Finland. Silva Fenn. 2006, 40, 443-458.

[53] McLane, S.C.; Daniels, L.D.; and Aitken, S.N. Climate impacts on lodgepole pine (Pinus contorta) radial growth in a provenance experiment. For. Ecol. Manag. 2011, 262, 115-123.

[54] Lombardero, M.J.; Ayres, M.P.; Lorio, P.L.; and Ruel, J.J. Environmental effects on constitutive and inducible resin defences of Pinus taeda. Ecol. Lett. 2000, 3, 329-339.

[55] Wang, Z.; Calderon, M.M.; and Carandang, M.G. Effects of resin tapping on optimal rotation age of pine plantation. J. For. Econ. 2006, 11, 245-260.

[56] Dickens, E.D. Fertilization options for longleaf pine stands on marginal soils with economic implications. The SOFEW 2001 Proceedings. Atlanta. GA. 27-28 March 2001.

[57] Matías, L.; and Jump, A.S. Interactions between growth, demography and biotic interactions in determining species range limits in a warming world: the case of Pinus Sylvestris. For. Ecol. Manag. 2012, 282, 10-22.

[58] Peňuelas, J.; Llusia, J. Seasonal emission of monoterpenes by the Mediterranean tree Quercus ilex L. in the field conditions. Relations with photosynthetic rates, temperature and volatility. Physiol. Plant. 1999. 105, 641-647.

[59] Parantainen, A.; and Pulkkine, P. Pollen viability of Scots pine (Pinus sylvestris) in different temperature conditions: high levels of variation among and within latitudes. For. Ecol. Manag. 2002, 167, 149-160.

[60] Salmela, M.J.; Cavers, S.; Cottrell, J.E.; Iason, G.R.; and Ennos, R.A. Seasonal patterns of photochemical capacity and spring phenology reveal genetic differentiation among native Scots pine (Pinus sylvestris L.) populations in Scotland. For. Ecol. Manag. $2011,262,1020-1029$.

[61] Maestre, F.T.; and Cortina, J. Are Pinus halepensis plantations useful as a restoration tool in semiarid Mediterranean areas? For. Ecol. Manag. 2004, 198, 303-317.

[62] Rodrigues, K.C.S.; Apel, M.A.; Henriques, A.T.; and Fett-Neto, A.G. Efficient oleoresin biomass production in pines using low cost metal containing stimulant paste. Biomass Bioenergy 2011, 35, 4442-4448.

[63] STN EN 14918, 2010 (65 7410) Solid fuels. Determination of calorific value.

[64] Chakradhar, S.; Pate, K.S. Combustion characteristics of tree woods. JSBS 2016, 6, 31-43.

[65] Rodrigues-Corrêa, K.C.S.; Lima, J.C.; Fett-Neto, A.G. Pine oleoresin: tapping green chemicals, biofuels, food protection, and carbon sequestration from multipurpose trees. Food Energy Secur. 2016, 1(2), 81-93.

[66] Zeneli, G.; Tsitsimpikou, C.; Petrakis, P.V.; Naxakis, G.; Habili, D.; and Roussis, V. Foliar and cortex oleoresin variability of Sliver fir (Abies alba Mill.) in Albania. Z. Naturforsch. 2001, 56c, 531-539.

[67] Dzurenda, L. Spal'ovanie dreva a kôry (Burning of wood and bark). Technical University in Zvolen 2005, 124 p. ISBN 80-2281555-1

[68] Singh, T.; and Kostecky, M.M. Calorific value variations in components of 10 Canadian tree species. Can. J. For. Res. 1986, 16, 6, 1378-1381.

[69] Haarke, A.P.; Sandels, A.; and Burley, J. Calorific values for wood and bark and a bibliography for fuel wood. In: Singh and Kostecky (1986). 
[70] Jain, R.K.; Singh, B. Fuelwood characteristics of selected indigenous tree species from central India. Bioresour. Technol. 1999, $68,3,305-308$.

[71] Rhén, C. Chemical composition and gross calorific value of the above-ground biomass components of young Picea abies. Scan. J. Forest. Res. 2004, 19, 72-81.

[72] Seth, M.K. Trees and their economic importance. Bot. Rev. 2003, 69, 4, 321-376.

[73] Abdel-Raouf, M.E.; and Abdul-Raheim, A.R.M. Rosin: Chemistry, Derivatives, and Applications: a review. BAOJ Chemistry $2018,4,1$.

[74] Simpraga, M.; Ghimire, R.P.; Van der Straeten, D.; Blande, J.D.; Kasurinen, A.; Sorvari, J.; et al. Unravelling the functions of biogenic volatiles in boreal and temperate forest ecosystems. Eur. J. For. Res. 2019, 5, 763-787.

[75] Maaten, E.; Mehl, A.; Wilmking, M.; and Maaten-Theunissen, M. Tapping the tree-ring archive for studying effects of resin extraction on the growth and climate sensitivity of Scots pine. For. Ecosyst. 2017, 4, 7. doi: 10.1186/s40663-017-0096-9

[76] Ivask, M. Caloric value of Norway spruce organs and its seasonal dynamics. Balt. For. 1999, 1, 44-49.

[77] Oszlany, J. Wood, bark, needles, leaves and roots energy values of Pinus sylvestris L., Picea excelsa Link. and Fagus sylvatica L. Ekológia (CSSR) (Ecology) 1982, 1, 289-296.

[78] Steublin, I.C.; Ramirez, M.A.; and Alberdi, M. Artenzusammensetzung, Lichtgenuss und Energiegehalt der Krautschicht des Valdvianischen Regelwaldes bei St. Matrin. In: Ivask (1999).

[79] Hughes, M.K. Seasonal calorific values from a deciduous woodland in England. Ecology 1971, 52, 923-926.

[80] Genova, M; Caminero, L.; Dochao, J. Resin tapping in Pinus pinaster: effects on growth and response function to climate. Eur. J. For. Res. 2014, 233, 323-333.

[81] Vallinayagam, R.; Vedharaj, S.; Yang, W.M.; Lee, P.S.; Chua, K.J.E.; Chou, S.K. Pine oil-biodiesel blends: A double biofuel strategy to completely eliminate the use of diesel in a diesel engine. Appl. Energy 2014, 130, 466-473. http://www.fao.org/docrep/005/y4496e/Y4496E27.htm (accessed on 8 October 2020)

[82] Acar, H.H.; Barli, O.; Youshimura,T. The effect of harvesting, transportation and stockpiling activities in the resin tapping on the resin productivity and quality. http://www.fao.org/3/y4496e/Y4496E27.htm (accessed on 20. December2020)

[83] Kossuth, S.V.; Roberts, D.; Huffman, J.; Wang, S.C. Resin acid, turpentine, and caloric content of paraquat-treated slash pine. Can. J. For. Res. 1982, 12, 489-492, doi: 10.1139/x82-076

[84] Papadopoulos, A.M. Resin tapping history of an Aleppo Pine forest in Central Greece. Open For. Sci. J. $2013,6,1,50-53$.

[85] Krokene, P.; Nagy, N.E. 5. Anatomical aspects of resin-based defenses in pine. In: Fett-Neto AG, and Rodrigues-Corrêa KCS. eds. Pine resin: biology, chemistry and applications. 2012, p. 67-86.

[86] Fox, T.R.; Jokela, E.J.; and Allen, H.L. The development of pine plantation silviculture in the southern United States. J. Forest 2007,105, 337-347.

[87] Perpiňa, C.C.; Kavalov, B.; Diogo, V.; Jakobs-Crisioni, C.; e Silva, F.B.; Lavalle, C. Agricultural land abandonment in the EU within 2025-2030, JRC 113718, European Commission 2018, Web: https://ec.europa.eu/eu/jrc/en/luisa (accessed on 3. March 2021)

[88] Ioelowich, M. Thermodynamics of biomass-based solid fuels. Academ. J. Polym. Sci. 2018, 2(1),

[89] Creuzburg, M.K.; Scheller, R.M.; Lucash, M.S.; Evers, L.B.; Ludec, S.D.; and Johnson, M.G. Bioenergy harvest, climate change, and forest carbon in the Oregon Coast Range. GCB Bioenergy 2016, 8, 357-370. doi: 10.1111/gcbb.12255

[90] Padilla, F.M.; Vidal, B.; Sánchez, J.; Pugnaire, F.I. Land-use changes and carbon sequestration through the twentieth century in a Mediterranean mountain ecosystem: Implications for land management. J. Environ. Manage. 2010, 91, 2688-2695.

[91] Bravo, F.; Bravo-Oviedo, A.; Diaz-Balteiro, L.; 2008. Carbon sequestration in Spanish Mediterranean forests under two management alternatives: a modelling approach. Eur. J. For. Res. 2008， $127 \quad$ (3), 225-234. http://link.springer.com/article/10.1007/s10342-007-0198-y

[92] Valentini, R.; Matteucci, G.; Dolman, A.J.; Schulze, E.D.; Rebmann, C.; Moors, E.J., et al. Respiration as the main determinant of carbon balance in European forests. Nature 2000, 404, 861-865.

[93] Zha, T., Kellomaki, S.; Wang, K.Y.; Rouvinen, I. Carbon sequestration and ecosystem respiration for 4 years in a Scots pine forest. Global Chang. Biol. 2004, 10, 1492-1503.

[94] Lee, J.; Tolunay, D.; Makineci, E.; Comez, A.; Son, Y.M.; Kim, R.; Son, Y. Estimating the age-dependent changes in carbon stocks of Scots pin (Pinus sylvestris L.) stands in Turkey. Ann. For. Sci. 2016, 73, 523-531.

[95] Sims, R.E.H.; Hastings, A.; Schlamadinger, B.; Taylor, G.; Smith, P. Energy crops: current status and future prospects. Global Change Biol. 2006, 12, 2054-2076.

[96] Dauern, J.; Jones, M.B.; Stout, A.C. The impact of biomass crop cultivation on temperate biodiversity. GCB Bioenergy 2010, 2, 289-309.

[97] Justine, M.F.; Yang, W.; Su, F.; Tan, B.; Khan, M.N. Biomass stock and carbon sequestration in a chronosequence of Pinus massoniana plantation in the upper reaches of Yangtze river. Forests 2015, 6, 3665-3682. doi: 10. 3390/f61033665

[98] Creutzig, F.; Ravindranath, N.H.; Berndes, G.; Bolwig, S.; Ryan Bright, R.; Cherubini, F. Bioenergy and climate change mitigation: an assessment. GCB Bioenergy 2014, 7, 5, 916-944. https://doi.org/10.1111/gcbb.12205 
[99] Pan, Y.; Birdsey, R.A.; Fang, J.; Houghton, R.; Kauppi, P.E.; Kurz, W.A. $\quad$ A large and persistent carbon sink in the world's forests. Science 2011, 333, 988-993.

[100] Bastin, J.F.; Finegold, Y.; Garcia, C.; Mollicone, D.; Rezende, M.; Routh, D.; et al. The global tree restoration potential. Science 2019, 365, 76-79. doi: 10. 1126/ science.aax0848

[101] Wu, W.; Hasegawa, T.; Fujimori, S.; Takahashi, K. Assessment of bioenergy potential and associated cost in Japan for the 21 ${ }^{\text {st }}$ century. Renew. Energy 2020, 162, 308-321.

[102] de Wit, M.; Faaij, A. European biomass resource potential and costs. Biomass Bioenergy 2010, 34, 188-202.

[103] Immerzeel, D.J.; Verweij, P.A.; van der Hilst, F.; Faaij, A.P.C. Biodiversity impacts of bioenergy crop production: a state-ofthe-art review. GCB Bioenergy 2014, 6, 183-209.

[104] Martínez, M.I.S. Analysis of miscanthus biomass for biofuel production. MSc. Minor Thesis Report. Wageningen University and Research Centre 2015, 25p.

[105] Nanda, S.; Rana, R.; Sarangi, P.K.; Dalai, A.K.; Kozinski, J.A. A Broad Introduction to First-, Second-, and Third-Generation Biofuels. In: Sarangi P., Nanda S., Mohanty P. (eds) Recent Advancements in Biofuels and Bioenergy Utilization. Springer, Singapore 2018, pp 1-25, https://doi.org/10.1007/978-981-13-1307-3_1

[106] Crutzen, P.J.; Mosier, A.R.; Smith, K.A.; Winiwarter, W. $\mathrm{N}_{2} \mathrm{O}$ release from agro-biofuel production negates global warming reduction by replacing fossil fuels. Atmospheric Chem. Phys. 2008, 8, 389-395.

[107] Nigam, P.S.; Singh, A. Production of liquid biofuels from renewable resources. Prog. Energy Combust 2011, 37, 52-68.

[108] Mohr, A.; Raman, S. Lessons from first generation biofuels and implications for the sustainability appraisal of second-generation biofuels. Energy Policy 2013, 63, 114-122.

[109] Naik, S.; Goud, V.V.; Rout, P.K.; Dalai, A.K. Production of the first- and second-generation biofuels: a comprehensive review. Renew. Sustain. Energy Rev. 2010, 14, 578-597.

[110] Palma, A.; Pestana, M.; and Azevedo, A. Pine resin sector in Portugal - weaknesses and challenges. For. Ideas 2012, 1, 1018.

[111] ARESB (Brazilian association of resin tapping companies) 2010, In: Rodrigues et al., 2011.

[112] Maga, J.; Piszczalka, J. Biomasa ako zdroj obnovitel’nej energie [Biomass as an energy renewable source]. Nitra. Slovenská pol’nohospodárska univerzita 2006, 108 p.

[113] Demko, J.; Machava, J.; Saniga, M. Energy production analysis of Common Reed - Phragmites australis (Cav.) Trin. Folia Oecol. 2017, 44, 2, 107-113.

[114] Pospíšil, R Pestovanie láskavca (Amaranthus) na výrobu bioplynu [Growing of amaranth for the biogas production]. Pôdohospodársky poradenský system. [Agricultural advisory system.] 2013, Available at: http://www.agroporadenstvo.sk/rastlinna-vyroba-energeticke-rastliny?article=202 (accessed 3. May 2020)

[115] Dauber.; J. Jones, M.B.; Stout, J.X. The impact of biomass crop cultivation on temperate biodiversity, GCB Bioenergy 2010, 2, 289-309. https://doi.org/10.1111/j.1757-1707.2010.01058.x

[116] Semere, T.; Slater, F. Ground flora, small mammal and bird species diversity in miscanthus (Miscanthusgiganteus) and reed canary-grass (Phalaris arundinacea) fields. Biomass Bioenergy 2007, 31, 20-29.

[117] Baum, C.; Leinweber, P.; Weih, M.; Lamersdorf, N.; Dimitrou, I. Effects of short rotation coppice with willows and poplar on soil ecology. Landbauforsch. Volkenrode 2009, 59, 3, 183-196.

[118] Tilman, D.; Hill, J.; Lehman, C. Carbon-negative biofuels from low-input high-diversity grassland biomass. Science 2006, 314, 1598-1600.

[119] WBGU (2009) Future Bioenergy and Sustainable Land Use. Earthscan, London and Sterling, VA.

[120] Fargione, J.; Hill, J.; Tilman, D.; Polasky, S.; Hawthorne, P. Land clearing and the biofuel carbon debt. Science 2008, 319, 12351238. doi: $10.1126 /$ science. 1152747

[121] Magnani, F.; Mencuccini, M.; Borghetti, M.; Berbigier, P.; Berninger, F.; Delzon, S.; Grelle A.; et al. The human footprint in the carbon cycle of temperate and boreal forests. Nature 2007, 447, 848-850. doi: 10. 1038/ nature05847

[122] Bergh, J.; Nilsson, U.; Allen, H.L.; Johansson, U.; Fahlvik, N. Long-term responses of Scots pine and Norway spruce stands in Sweden to repeated fertilization and thinning. For. Ecol. Manag. 2014, 320, 118-128. doi: 10. 1016/j.foreco. 2014. 02.016

[123] Griscom, B.W.; Adams, J.; Ellis, P.W.; Houghton, R.A.; Lomax, G.; Miteva, D.A.; et al. Natural climate solutions. Proc. Natl. Acad. Sci. 2017, 114, 11645-11650. doi: 10. 1073/pnas. 1710465114

[124] Shan, J.; Morris, L.A.; and Hendrick, R.L. The effects of management on soil and plant carbon sequestration in slash pine plantations. J. Appl. Ecol. 2001, 38, 932-941.

[125] Balboa-Murias, M.A.; Rodríguez-Soalleiro, R.; Merino, A.; and Àlvarez-González, J.G. Temporal variation and distribution of carbon stocks in aboveground biomass of radiata pine and maritime pine pure stands under different silvicultural alternatives. For. Ecol. Manag. 2006, 237, 29-38.

[126] Coley, D.R.; Coleman, M.D.; and Aubrey, D.P. Above- and below-ground biomass accumulation, production, and distribution of sweetgum and loblolly pine grown with irrigation and fertilization. Can. J. For. Res. 2008, 38, 1335-1348. 
[127] Abbas, D.; Abdelgadir, I.; Alvarez, S.; Andrasko, K.; Animon, I.; Baker, K. Forestry for a low-carbon future: Integrating forests and wood products in climate change strategies. Food and Agriculture Organization of the United Nations. Rome 2016, FAO For. Pap. 177, 180p. SBN 978-92-5-109312-2

[128] Farley, K.A.; Kelly, E.F.; Hofstede, R.G.M. Soil organic carbon and water retention after conversion of grasslands to pine plantations in the Ecuadorian Andes. Ecosystems 2004, 7, 729-739.

[129] Malmsheimer, R.W.; Heffernan, P.; Brink, S.; Crandall, D.; Deneke, F.; Galik, CS.; et al. Preventing GHG emissions through biomass substitution. J. For. 2008, 106, 136-140.

[130] Spath, P.L.; Mann, M.K. Biomass Power and Conventional Fossil Systems with and without $\mathrm{CO}_{2}$ Sequestration - Comparing the Energy Balance, Greenhouse Gas Emissions and Economics. Golden, Technical report, Colorado 80401-3393 NREL/TP510-32575, 2004, 28p.

[131] IPCC (Intergovernmental Panel on Climate Change). Land use, land-use change, and forestry. A special report of the Intergovernmental Panel on Climate Change ed. R.T. Watson, I.R. Noble, B. Bolin, N.H. Ravindranath, D.J. Verardo \& D.J. Dokken. Cambridge, UK, Cambridge University Press. (IPCC, 2000)

[132] IPCC (Intergovernmental Panel on Climate Change,) An IPCC special report on the impacts of global warming of $1.5^{\circ} \mathrm{C}$ above pre-industrial levels and related global greenhouse gas emission pathways (IPCC, 2018).

[133] Federici, S.; Tubiello, F.N.; Salvatore, M.; Jacobs, H.; \& Schmidhuber, J. New estimates of $\mathrm{CO}_{2}$ forest emissions and removals: 1990-2015. For. Ecol. Manag. 2015, 352, 89-98.

[134] Andreani-Aksoyoglu, S.; Keller, J. 1995. Estimates of monoterpene and isoprene emissions from the forests in Switzerland. J. Atmos. Chem. 1995, 20, 71-87.

[135] Shürmann, W. Emission von Monoterpenen aus Nadeln von Picea Abies (L.) Karst, sowie deren Verhalten in der Atmosphere, In: Andreani-Aksoyoglu, S.; Keller, J. [134]

[136] Janson, R. 1992. Monoterpene concentration in and above a forest of Scots pine. In: Andreani-Aksoyoglu, S.; Keller, J. [134]

[137]Tingey, D.T.; Manning, M.; Grothaus, L.C.; and Burns, W.F. Influence on light and temperature on monoterpene emission rates from Slash pine. Plant Physiol. 1980, 65, 797-801.

[138] Ruiz-Peinado, R.; Bravo-Oviedo, A.; López-Senespleda, E.; Felipe Bravo, F.; and del Río, M. Forest management and carbon sequestration in the Mediterranean region: A review. For. Sys. 2017, 16(2), 25p. https://doi.org/10.5424/fs/2017262-11205

[139] Tubiello, V.N.; Conchedda, G.; Wanner, N.; Federici, S.; Rossi, S.; and Grassi, G. Carbon emissions and removals from forests: new estimates, 1990 - 2020. Earth Syst. Sci. Data 2021, 13, 1681-1691.

[140] Jörgensen, K.; Granath, G.; Lindahl, B.D.; Strengborn, J. Forest management to increase carbon sequestration on boreal Pinus sylvestris forests. Plant and Soil 2021, https://d+oi.org/10.1007/s11104-021-05038-0

141] van der Hilst, F.; Vestegen, J.A.; Karssenberg, D.; Faaij, A.P.C. Spatiotemporal land use modelling to assess land availability for energy crops - illustrated for Mazambique. GCB Bioenergy 2012, 4, 859-874. doi: 10.1111/j.1757-1707.2011.01147.x

142] Zhu, J.Y.; Zhuang, X.S. Conceptual net energy output for biofuel production from lignocellulosic biomass through biorefining. Prog. Energy Combust. Sci. 2012, 38, 583-598.

143] Abdeshahian, P.; Dashti, M.G.; Kalil, M.S.; and Yusoff, W.M.W. Production of biofuel using biomass as a sustainable biological resource. Biot. 2010, 9, 3, 274-282. doi: 10.3923/biotech.2010.274.282

144] Westbrook, J.W.; Walker, A.R.; Neves, L.G.; Munoz, P.; Resende Jr, M.F.R.; Neale, D.B. et al. Discovering candidate genes that regulate resin canal number in Pinus taeda stems by integrating genetic analysis across environments, ages, and populations. New Phytol. 2015, 205, 2, 627-641. 